\title{
Detecção por DAS-ELISA do Apple chlorotic leaf spot virus em Pétalas Desidratadas de Macieira Mantidas em Geladeira por 16 Anos
}

\author{
Juliana Freitas-Astua', Quelmo S. de Novaes², Juarez A. Betti ${ }^{3}$, Jorge A.M. Rezende'2, Hugo Kuniyuki ${ }^{3}$ \\ \& Valdir A. Yuki ${ }^{3}$
}

${ }^{1}$ Embrapa Milho e Sorgo/ Centro APTA Citros ‘Sylvio Moreira', CEP 13490-970, Cordeirópolis, SP, ${ }^{2}$ Departamento de Entomologia, Fitopatologia e Zoologia Agrícola, ESALQ, USP, CEP 13418-900, Piracicaba, SP, ${ }^{3}$ Centro de Fitossanidade, Instituto Agronômico, CEP13020-902, Campinas, SP, e-mail: jabetti@iac.sp.gov.br

(Aceito para publicação em 31/03/2004)

Autor para correspondência: Juarez Antonio Betti

\begin{abstract}
DAS-ELISA detection of Apple chlorotic leaf spot virus in dehydrated apple petals stored under refrigeration for 16 years

Flower petals of eleven apple (Malus domestica) clones doubly infected with Apple chlorotic leaf spot virus (ACLSV) and Apple stem grooving virus (ASGV) were harvested in 1985, dehydrated in calcium

chloride and stored in the refrigerator at $4-5^{\circ} \mathrm{C}$. Petals from fourteen virus free clones were also stored at the same time. DAS-ELISA with antisera against both viruses detected ACLSV in petals from eight clones after sixteen years of storage. ASGV was not detected in any clone. All virus free clones tested negative for both viruses.
\end{abstract}

Os vírus da mancha clorótica da folha da macieira (Apple chlorotic leaf spot virus - ACLSV, Trichovirus) e do acanalamento do lenho da macieira (Apple stem grooving virus -ASGV, Capillovirus), assinalados inicialmente no Brasil com base em características biológicas e da partícula viral (Rev. Soc. Brasil. Fitopatol. 5:125. 1972), tiveram a identidade confirmada por meio de ISEM (Summa Phytopatol. 11:62. 1985) e RT-PCR (Fitopatol Bras. 24:444. 1999). Esses vírus foram associados à necrose interna do porta-enxerto Maruba-kaido em mudas de macieira (Summa Phytopathol. 14:33. 1988; Fitopatol. Bras. 26:655. 2001), mas normalmente ocorrem sem causar sintomas diagnósticos.

Pétalas de flores de macieiras estabelecidas a céu aberto no Centro Experimental Central do IAC, Campinas, SP foram coletadas em 18/9/1985 e colocadas em frascos de vidro de 10 $\mathrm{ml}$, contendo 3,5 g de cloreto de cálcio e sobre ele um chumaço de algodão, para evitar o contato direto do sal com as pétalas. A desidratação e a manutenção das pétalas ocorreram em geladeira $\left(4-5{ }^{\circ} \mathrm{C}\right)$. Onze amostras foram obtidas de plantas infetadas conjuntamente com o ACLSV e o ASGV, referentes a clones originários de Paranapanema e Angatuba, SP. Catorze amostras representaram clones resultantes de termoterapia determinados livres dos dois vírus por meio de testes biológicos e ISEM (Summa Phytopathol. 12:19. 1985).

Em fevereiro de 2002, as amostras foram submetidas à detecção por DAS-ELISA (kit Bioreba) para o ACLSV (duas replicações) e o ASGV (três replicações), na ESALQ-USP, Piracicaba, SP. Valores médios de absorbância $\left(\mathrm{A}_{405 \mathrm{~nm}}\right)$ dos extratos de pétalas de pelo menos duas vezes o valor médio dos controles negativos foram considerados como positivos. Os resultados na Tabela 1 indicam que o ACLSV foi detectado em oito das onze amostras provenientes de plantas infetadas. Todas as amostras de clones de termoterapia apresentaram resultados negativos, confirmando os testes biológicos e de ISEM realizados anteriormente. Os resultados para o ASGV foram totalmente negativos, mesmo para pétalas provenientes de plantas infetadas, indicando que o vírus não mais estava presente numa forma detectável pelo método empregado. $\mathrm{O}$ ACLSV apresenta ponto final de inativação térmica e longevidade in vitro inferiores ao ASGV, o inverso do que ocorreu para o vírus em pétalas desidratadas mantidas em geladeira. Não foram encontrados relatos sobre o comportamento desses vírus após anos de armazenagem.

TABELA 1 - Valores médios de absorbância $\left(\mathrm{A}_{405 \mathrm{~nm}}\right)$ de DAS-ELISA na detecção de Apple stem grooving virus (ASGV) e Apple chlorotic leaf spot virus (ACLSV) em pétalas desidratadas de macieira armazenadas durante 16 anos em geladeira

\begin{tabular}{|c|c|c|c|c|}
\hline \multirow{2}{*}{\multicolumn{2}{|c|}{ Amostra }} & \multicolumn{3}{|c|}{$\begin{array}{c}\mathrm{A}_{405 \mathrm{~nm}} \text { * após a incubação } \\
\text { indicada }\end{array}$} \\
\hline & & \multirow{2}{*}{$\begin{array}{c}\text { ASGV } \\
4 h \\
\end{array}$} & \multicolumn{2}{|c|}{ ACLSV } \\
\hline & & & & \\
\hline 1 & Anna 269/3A & 0,075 & 0,119 & $\mathbf{0 , 5 9 1}$ \\
\hline 2 & Anna EF 269/5 & 0,031 & 0,341 & 1,419 \\
\hline 3 & Brasil 270/4B & 0,063 & 0,109 & 0,514 \\
\hline 4 & Rainha 230/4B (Planta 1) & 0,065 & 0,149 & 0,640 \\
\hline 5 & Rainha 230/4B (Planta 2) & 0,070 & 0,161 & 0,745 \\
\hline 6 & Rainha 271/1A & 0,060 & 0,076 & 0,331 \\
\hline 7 & Rainha 271/2A (Planta 1) & 0,067 & 0,028 & 0,163 \\
\hline 8 & Rainha 271/2A (Planta 2) & 0,065 & 0,036 & 0,152 \\
\hline 8 & Ohio Beauty 269/4A & 0,075 & 0,181 & 0,824 \\
\hline 9 & Ohio Beauty 270/6B & 0,064 & 0,055 & 0,286 \\
\hline 10 & Ohio Beauty 272/2B (Planta 1 ) & 0,062 & 0,236 & 1,060 \\
\hline 11 & Ohio Beauty 272/2B (Planta 2) & 0,015 & $\mathbf{0 , 5 5 5}$ & 2,123 \\
\hline \multicolumn{2}{|c|}{ Controle negativo } & 0,071 & 0,045 & 0,188 \\
\hline \multicolumn{2}{|c|}{ Controle positivo } & 0,299 & 0,154 & 0,614 \\
\hline
\end{tabular}

*Amostras consideradas positivas estão grifadas em negrito 